\title{
A prospective evaluation of obesometric parameters associated with renal stone recurrence
}

\author{
Derek Bos, MD;' Shawn Dason, MD;i Edward Matsumoto, MD;1 Jehonathan Pinthus, MD;1 \\ Christopher Allard, $M D^{1,2,3}$
}

'McMaster University, Hamilton, ON, Canada, ${ }^{2}$ Massachusetts General Hospital, Boston, MA, United States; ${ }^{3 B r i g h a m ~ a n d ~ W o m e n ' s ~ H o s p i t a l, ~ B o s t o n, ~ M A, ~ U n i t e d ~ S t a t e s ~}$

Cite as: Can Urol Assoc J 2016;10(7-8):234-8. htrp://dx.doi.org/10.5489/cuai.3876

See related commentary on page 239.

\section{Abstract}

Introduction: Our aim was to evaluate whether obesometric serum hormones and body fat distribution are associated with renal stone recurrence.

Methods: We conducted a prospective cohort study of participants undergoing renal stone (RS) intervention at a single institution from November 2009-June 2010 and followed them for a median 62 months. Obesometric parameters were measured at baseline, including body mass index (BMI), fasting serum leptin and adiponectin, and proportion of visceral adipose tissue (\%VAT) averaged from three fixed axial computed tomography (CT) slices. The primary study outcome was stone recurrence.

Results: A total of 110 participants were enrolled. Elevated \%VAT was associated RS recurrence; participants with \%VAT in the highest quartile had a five-year stone-free rate of $47.1 \%$ compared to $72.2 \%$ among other participants $(p=0.004)$. Adjusting for gender, elevated \%VAT was independently predictive of renal stone recurrence among initial stone formers $(n=74$; hazard ratio [HR] 4.53, 95\% confidence interval $[\mathrm{Cl}] 1.08-19.02)$, but not among recurrent stone formers $(n=19$; HR 0.51, 95\% Cl 0.054-4.72). Other obesometric factors, including leptin, adiponectin, and $\mathrm{BMI}$, were not significantly predictive of recurrence.

Conclusions: We report a novel association between an elevated $\%$ VAT and stone recurrence. These findings may inform patient counselling and followup regimens. The metabolic basis for these findings requires further investigation.

\section{Introduction}

Renal stones affect up to $13 \%$ of the population. ${ }^{1}$ The incidence of renal stones varies depending on age, gender, race, geographic location, family history, and comorbidities. ${ }^{2}$ Obesity is an established risk factor, and the rising incidence of stones in North America has been hypothesized to relate to the obesity epidemic. ${ }^{3}$ The incidence and severity of obesity are commonly quantified by body mass index (BMI). However, BMI is limited in its ability to discriminate body fat from lean body mass and is an imperfect predictor of metabolic sequelae of obesity. ${ }^{4}$ Various alternative definitions of obesity have been proposed to more accurately identify risk factors for obesity-related morbidity. ${ }^{5}$

The proportion of visceral adipose tissue (\%VAT), as opposed to subcutaneous adipose tissue (\%SAT), is an important obesometric parameter that predicts adverse metabolic and cardiovascular outcomes independent of BMI. ${ }^{6-8}$ Additionally, levels of the circulating hormones leptin and adiponectin correlate with obesity and its complications; elevated leptin and reduced adiponectin independently predict the metabolic syndrome and future cardiovascular disease. $^{9-12}$

Although \%VAT and circulating hormones may better define obesity, BMI has been used in past studies assessing the relationship between obesity and renal stone disease. ${ }^{13,14}$ The possible importance of additional obesometric factors, such as \%VAT and circulating hormones, have not been sufficiently explored. These parameters offer objective measures, which may be useful in determining an individual's probability of stone formation or recurrence.

This study's objective was to investigate associations between obesometric parameters, including BMI, \%VAT, and serum hormone levels, with renal stone recurrence in a prospective cohort of patients undergoing renal stone intervention at a single academic hospital.

\section{Methods}

All participants undergoing renal stone intervention (extracorporeal shockwave lithotripsy [ESWL], percutaneous nephrolithotomy, or ureteroscopy) at St. Joseph's Healthcare, Hamilton, ON, Canada, were offered prospective enrolment from November 2009 through June 2010. Participants 
with residual stone burden after treatment were excluded. Institutional review board approval and informed consent were obtained prior to study onset.

Obesometric factors were measured at baseline at the time of stone intervention. Height and weight were measured to calculate BMI (weight/height ${ }^{2}$ ). Patient history and referral notes were reviewed to identify comorbidities, including diabetes. Serum leptin and adiponectin were drawn after an overnight fast and measured in triplicates using dedicated enzyme-linked immunosorbent assay (ELISA) kits (B-bridge international, Inc. CA, U.S.).

Computed tomography (CT) scans were performed at baseline to determine body fat distribution. Visceral and subcutaneous adipose tissues were identified using commercially available software (Photoshop and Clear Image Demo). Tissue of fat density (defined as Hounsfield units [HU] -250 to -50 ) was isolated and the pixels comprising fat tissue were summed and averaged across three fixed axial slices (L2 vertebral body, umbilicus, and anterior superior iliac spine) in accordance with previously described methodology (Fig. 1). ${ }^{15,16}$ The \%VAT was defined as average visceral adipose tissue divided by the average total adipose tissue $\times 100 \%$, where total adipose tissue comprised visceral and subcutaneous adipose tissues. ${ }^{4,14}$ Skin-to-stone distance (SSD) was measured as the mean of distances at 0,45 , and 90 degrees from the skin edge, in keeping with past methodology. ${ }^{16-18}$

After initial stone intervention, participants were followed with serial kidney-ureter-bladder (KUB) ultrasound and/or plain radiograph at both six weeks and six months post-treatment, then yearly thereafter. CT scan was used in participants with new-onset pain, increased stone burden, or when planning repeat intervention. The primary outcome was stone recurrence, defined as repeat intervention for recurrent stones. Indications for re-intervention included symptomatic, enlarging, or obstructing stones.

Univariate and multivariable predictors of stone recur- rence were evaluated by log rank tests and Cox proportional hazards regressions, respectively. Multivariable models were constructed, adjusting for gender and stratifying by previous history of stones. These were selected a priori as two established risk factors for recurrence. Kaplan-Meier survival analysis was used to determine timing to stone recurrence. Statistical analyses were performed using Stata 13 (StataCorp LP, College Station, TX, U.S.). All tests were two-sided, with $p$ value $<0.05$ defining statistical significance.

\section{Results}

\section{Cohort}

A total of 110 participants were enrolled in the study, including 70 males (63.4\%) and 40 females (36.6\%). Mean age was 54.5 years (range 19-89). Baseline patient characteristics are shown in Table 1. Among our study population, 60 (55\%), 33 (30\%), and $17(16 \%)$ participants initially underwent treatment by ureteroscopy and laser lithotripsy, ESWL, and percutaneous nephrolithotomy, respectively. Twentyeight $(30.1 \%)$ participants developed stone recurrence at a median 61.9 months.

\section{Obesometric parameters}

Participants had a mean height of $171.5 \mathrm{~cm}$ (range 148-193), weight of $87.2 \mathrm{~kg}$ (range 41-102.6kg), and BMI of 30 (range18.7-56.6). Only $23 \%$ of participants had BMI within the normal range $\left(20-24.9 \mathrm{~kg} / \mathrm{m}^{2}\right)$, while $37 \%$ were overweight (BMI 25-29.9 kg/m²), 22\% obese (BMI 30-34.9 $\left.\mathrm{kg} / \mathrm{m}^{2}\right)$, and $17 \%$ morbidly obese $\left(\mathrm{BMI} \geq 35 \mathrm{~kg} / \mathrm{m}^{2}\right)$ by conventional definitions. ${ }^{19}$ Nineteen participants $(17.2 \%)$ had a previous history of stone treatment. Males and females had mean \%VAT of 46.9 and 28.4 , respectively $(\mathrm{p}<0.001)$,
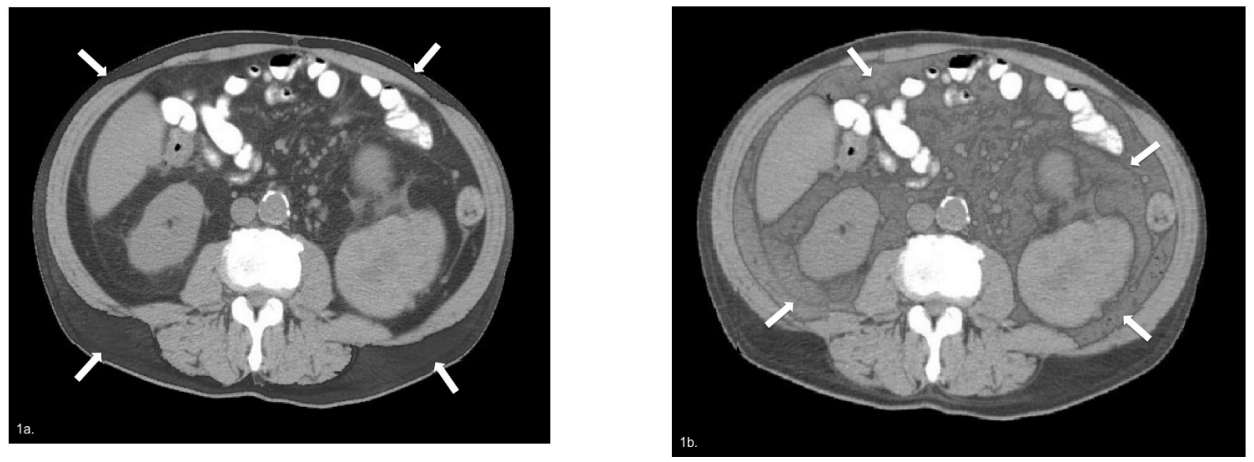

Fig. 1. Computed tomography scan images used in the measurement of percentage of visceral adipose tissue (\%VAT). Subcutaneous adipose tissue (SAT) is highlighted on the left and visceral adipose tissue (VAT) on the right. SAT and VAT pixels are summed at three fixed axial slices. \%VAT is calculated by VAT/ (VAT+SAT) x 100\%. 
Bos et al.

\begin{tabular}{|c|c|c|c|}
\hline Baseline characteristic & $\begin{array}{l}\text { Male } \\
(n=70)\end{array}$ & $\begin{array}{c}\text { Female } \\
(n=40)\end{array}$ & $\begin{array}{l}\text { Overall } \\
(n=110)\end{array}$ \\
\hline Mean age, years (range) & $54.9(25-82)$ & $54.2(19-89)$ & $54.5(19-89)$ \\
\hline \multicolumn{4}{|l|}{$\begin{array}{l}\text { Previous history of } \\
\text { stones }\end{array}$} \\
\hline No & 59 & 32 & $91(82.7)$ \\
\hline Yes & 11 & 8 & $19(17.3)$ \\
\hline \multicolumn{4}{|l|}{ Type of procedure, n (\%) } \\
\hline URS + laser lithotripsy & 32 & 28 & $60(54.5)$ \\
\hline ESWL & 18 & 15 & $33(30.0)$ \\
\hline PCNL & 11 & 5 & $17(15.5)$ \\
\hline $\begin{array}{l}\text { Body mass index, } \\
\text { mean } \mathrm{kg} / \mathrm{m}^{2}(\mathrm{SD})\end{array}$ & $28.7(6.0)$ & $32.4(9.5)$ & $30.0(7.6)$ \\
\hline $\begin{array}{l}\text { Visceral adipose tissue*, } \\
\text { mean } \% \text { (SD) }\end{array}$ & $46.94(9.6)$ & $28.4(9.0)$ & $40.1(12.9)$ \\
\hline $\begin{array}{l}\text { Adiponectin, } \\
\text { mean } \mathrm{mcg} / \mathrm{mL} \text { (SD) }\end{array}$ & $5.55(3.8)$ & $10.91(8.9)$ & $7.67(6.9)$ \\
\hline $\begin{array}{l}\text { Leptin*, } \\
\text { mean ng/mL (SD) }\end{array}$ & $7.6(9.0)$ & $32.0(30.3)$ & $17.5(23.7)$ \\
\hline $\begin{array}{l}\text { Skin-to-stone distance, } \\
\text { mean cm (SD) }\end{array}$ & $9.86(2.1)$ & $11.26(3.3)$ & $10.3(2.7)$ \\
\hline $\begin{array}{l}\text { Stone Hounsfield units } \\
\text { (SD) }\end{array}$ & $\begin{array}{l}921.26 \\
(369.0)\end{array}$ & $\begin{array}{l}919.36 \\
(389.3)\end{array}$ & $\begin{array}{c}910.5 \\
(378.6)\end{array}$ \\
\hline
\end{tabular}

indicating higher proportions of visceral fat in males and of subcutaneous fat in females. Mean leptin levels were higher in females ( 30.35 vs. $7.60 ; p<0.001)$, as were mean adiponectin levels ( 10.91 vs. $5.55 ; p=006)$. The mean stone HU was 910.5 and mean SSD was $10.3 \mathrm{~cm}$, with no significant gender differences.

In univariate analyses, a previous history of renal stones and elevated \%VAT (defined a priori as the highest quartile) were each associated with stone recurrence (Table 2); elevated $\%$ VAT $(\geq 50.6 \%)$ was associated with a five-year stone-free rate (SFR) of $47.1 \%$ compared with $72.2 \%$ among participants without elevated \%VAT $(<50.6)(p=0.004)$ (Fig. 2).

Participants with and without a past history of renal stones at baseline had a five-year SFR of $31.6 \%$ and $81.6 \%$, respectively $(\mathrm{p}<0.001)$ (Fig. 3). Males and females had a five-year SFR of $70 \%$ and $74 \%$, respectively $(p=0.56)$, while elevated leptin (defined by highest quartile, $>24.6 \mathrm{ng} / \mathrm{ml}$ ) and low adiponectin levels (defined by lowest quartile, $<3.12 \mathrm{ug} /$ $\mathrm{ml})$, demonstrated a five-year SFR of $66.7 \%(\mathrm{p}=0.69)$ and $70.5 \%$ ( $p=0.55)$. Traditionally defined obesity (BMI $\geq 30 \mathrm{~kg} /$ $\mathrm{m}^{2}$ ) was not associated with stone recurrence (five-year SFR $71.1 \%$ vs. $71.6 \%$ among obese and non-obese participants, respectively $(p=0.73)$. We found no association between any of diabetes, SSD, HU, or stone size and five-year SFR $(\mathrm{p}>0.05)$.

\begin{tabular}{|c|c|c|}
\hline Baseline characteristic & Five-year SFR, \% & $p$ value \\
\hline \multicolumn{3}{|l|}{ Gender } \\
\hline Male & 70.0 & 0.56 \\
\hline Female & 74.0 & \\
\hline \multicolumn{3}{|l|}{ Age } \\
\hline $19-45$ & 78.0 & 0.71 \\
\hline $45-54$ & 59.6 & \\
\hline $55-64$ & 80.0 & \\
\hline $65-74$ & 70.0 & \\
\hline$>74$ & 61.5 & \\
\hline \multicolumn{3}{|l|}{ Obese (BMI $\geq 30$ ) } \\
\hline No & 71.6 & 0.73 \\
\hline Yes & 71.1 & \\
\hline \multicolumn{3}{|l|}{ Diabetes } \\
\hline No & 70.3 & 0.98 \\
\hline Yes & 68.8 & \\
\hline \multicolumn{3}{|c|}{ History of nephrolithiasis } \\
\hline No & 81.6 & $<0.001$ \\
\hline Yes & 31.6 & \\
\hline \multicolumn{3}{|l|}{ Elevated leptin* } \\
\hline No & 71.3 & 0.69 \\
\hline Yes & 66.7 & \\
\hline \multicolumn{3}{|l|}{ Low adiponectin** } \\
\hline No & 70.5 & 0.55 \\
\hline Yes & 75.0 & \\
\hline \multicolumn{3}{|l|}{ Elevated \%VAT* } \\
\hline No & 79.3 & 0.004 \\
\hline Yes & 47.1 & \\
\hline \multicolumn{3}{|l|}{ Low \%VAT** } \\
\hline No & 71.0 & 0.66 \\
\hline Yes & 72.2 & \\
\hline \multicolumn{3}{|l|}{ Elevated SSD* } \\
\hline No & 68.5 & 0.67 \\
\hline Yes & 66.2 & \\
\hline
\end{tabular}

*defined by highest quartile; ${ }^{* *}$ defined by lowest quartile; BMI: body mass index; SFR stone-free rate; SSD: skin-to-stone distance; VAT: visceral adipose tissue.

In stratified multivariable analyses adjusting for gender, $\%$ VAT was independently predictive of stone recurrence among participants without a history of recurrent stone formation ( $n=74$, hazard ratio [HR] 4.53, 95\% confidence interval $[\mathrm{Cl}]$ 1.08-19.02). We found no independent association between \%VAT and recurrence among recurrent stone formers ( $n=19$, HR 0.51, 95\% Cl 0.054-4.72).

\section{Discussion}

Obesity, defined traditionally by an elevated BMI, is an established risk factor for renal stone formation and recurrence. ${ }^{13,14}$ The pitfalls of defining obesity according to BMI are increasingly apparent. ${ }^{8-10}$ This study describes a novel 


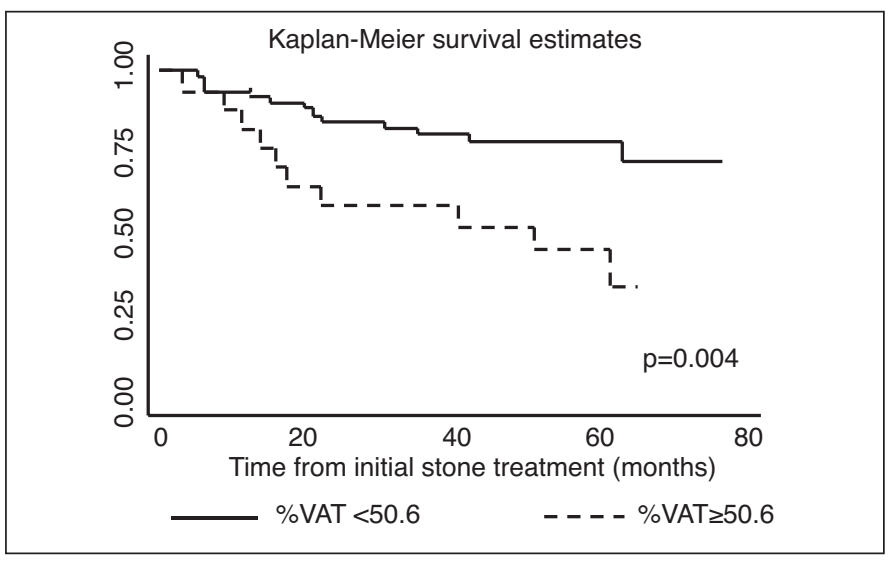

Fig. 2. Kaplan-Meier curve demonstrating association between elevated \%VAT (highest quartile) and decreased time to stone recurrence.

association between elevated visceral fat distribution and time to renal stone recurrence after a median five years of followup. While the majority of participants enrolled in this study were overweight or obese $(76 \%)$, we did not observe a similar relationship between BMI and stone recurrence.

Obesity is the focus of many public health efforts in North America due to its increasing prevalence and diverse health implications, including renal stone formation. ${ }^{20,21}$ The mechanism(s) by which obesity increases the risk of stone formation is uncertain, with several hypothesized explanations, including an increased intake of lithogenic substances and higher rates of urinary oxalate excretion. ${ }^{22-24}$ Renal stones are a major cause of morbidity and pose a significant economic burden. The identification and characterization of common modifiable risk factors may result in new approaches to treatment and prevention, benefiting patients and reducing healthcare expenditures.

The limitation of BMI in describing obesity has received increasing attention and alternatives, such as \%VAT, have been proposed as more accurate predictors of obesity-related morbidities. ${ }^{5-9}$ The proposed mechanism by which \%VAT may be a better predictor than BMI in predicting renal stone disease, is due to its more direct association with the metabolic derangement seen in patients who suffer from obesity. ${ }^{25}$ While diabetes has been linked to stone recurrence, insulin resistance has been strongly associated with visceral fat. Much of the focus has been on insulin resistance and the role it plays, not only in diabetes, but cardiovascular disease, as well as hypertension and obesity. ${ }^{25}$ With the knowledge that $\mathrm{BMI}$ has been connected to renal stone recurrence, our study hoped to better understand the possible association that may exist between \%VAT and stone formers.

In addition to elevated \%VAT, we observed an increased risk of stone recurrence $(68.4 \%)$ among participants with a past history of stones. This observation is in keeping with past studies, which demonstrate recurrence to be as high as $50 \%$ among stone formers at $5-7$ years following an initial

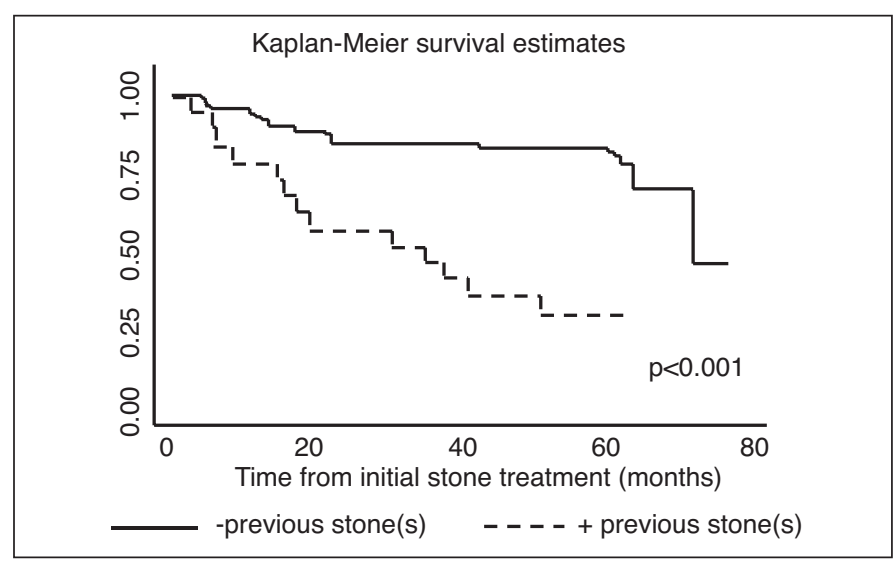

Fig. 3. Kaplan-Meier survival curve demonstrating association between previous history of nephrolithiasis and decreased time to stone recurrence.

stone episode. ${ }^{1}$ In subset analyses, \%VAT was predictive of stone recurrence among initial stone formers, but not among participants with recurrent disease. This apparent discrepancy may result from a number of factors, including the low sample size of participants with recurrent stones or effect modification related to stone history (i.e., participants who have already developed multiple renal stones are at such high risk for future recurrence as to render \%VAT irrelevant).

We observed no association between gender and stone recurrence. The role of gender in the incidence of urolithiasis has been controversial. While most studies have described an increased stone risk in males, ${ }^{26,27}$ a recent study by Cho et al observed no significant difference between genders. ${ }^{28}$ It has been shown that obesity increases the risk of stones disproportionately more in women than men, and since our cohort was primarily overweight or obese, the high prevalence of obesity may have equalized the stone recurrence risk between the sexes.

The limitations of our study deserve mention. It describes a cohort of patients at a single academic institution in Canada, thus potentially limiting its generalizability to other populations (although obesity rates in Canada are similar to those in the whole of North America, as well as Western Europe). ${ }^{29}$ Further, we did not have sufficient data relating to stone composition, a potentially relevant predictor of stone recurrence. Although followup was standardized, the possibility exists that some patients may have presented with acute renal colic to outside institutions. Lifestyle factors related to stone formation, such as diet and fluid intake, were not quantified. Finally, our cohort was comprised of individuals with renal stones and our findings cannot be extrapolated to the general population without further study.

\section{Conclusion}

In this single-centre, prospective study, body fat distribution was significantly associated with stone recurrence. 
Bos et al.

These findings, pending external validation, could inform patient counselling and individualized followup regimens. The metabolic basis underlying these observations requires further investigation.

Competing interests: The authors report no competing personal or financial interests.

This paper has been peer-reviewed.

\section{References}

1. Lotan Y, Buendia Jimenez I, Lenoir-Wiinkoop I, et al. Primary prevention of nephrolithiasis is cost-effective for a national healthcare system. BJU Int 2012;110:E1060-7. http://dx.doi.org/10.1111/j.1464410X.2012.11212.x

2. Romero V, Akpinar H, Assimos D. Kidney stones: A global picture of prevalence, incidence, and associated risk factors. Rev Urol 2010;12:e86-e96.

3. Wild S, Roglic G, Green A, et al. Global prevalence of diabetes: Estimates for the year 2000 and projections for 2030. Diabetes Care 2004;27:1047-53. http://dx.doi.org/10.2337/diacare.27.5.1047

4. Shuster A, Patlas M, Pinthus JH, et al. The clinical importance of visceral adiposity: A critical review of methods for visceral adipose tissue analysis. Br J Radiol 2012;85:1-10. http://dx.doi.org/10.1259/ bir $/ 38447238$

5. Britton KA, Massaro JM, Murabito JM, et al. Body fat distribution, incident cardiovascular disease, cancer, and all-cause mortality. J Am Coll Cardiol 2013;62:921-5. http://dx.doi.org/10.1016/i. jacc.2013.06.027

6. Zhang X, Shu XO, Yang G, et al. Abdominal obesity and mortality in Chinese women. Arch Intern Med 2007;167:886-92. http://dx.doi.org/10.1001/archinte.167.9.886

7. Kuk JL, Katzmarzyk PT, Nichaman MZ, et al. Visceral fat is an independent predictor of all-cause mortality in men. Obesity 2006;14:336-41. http://dx.doi.org/10.1038/oby.2006.43

8. Fox CS, Hwang SJ, Massaro JM, et al. Relation of subcutaneous and visceral adipose tissue to coronary and abdominal aortic calcium (from the Framingham heart study). Am J Cardiol 2009; 104:543-7. htrp:// dx.doi.org/10.1016/i.amicard.2009.04.019

9. Urbonaviciene G, Frystyk J, Flyvbjerg A, et al. Association of serum adiponectin with risk for cardiovascular events in patients with peripheral arterial disease. Atherosclerosis 2010;210:619-24. http://dx.doi. org/10.1016/i.atherosclerosis.2009.12.030

10. Kaiser $O M$, Johnson DW, Prins JB, et al. The role of novel biomarkers of cardiovascular disease in chronic kidney disease: Focus on adiponectin and leptin. Curr Cardiol Rev 2008;4:287-92. http://dx.doi. org/10.2174/157340308786349516

11. Patel SB, Reams GP, Spear RM, et al. Leptin: Linking obesity, the metabolic syndrome, and cardiovascular disease. Curr Hypertens Rep 2008;10:131-7. http://dx.doi.org/10.1007/s11906-008-0025-y

12. Kotani K, Sakane N, Saiga K, et al. Leptin: Adiponectin ratio as an atherosclerotic index in patients with type 2 diabetes: Relationship of the index to carotid intima-media thickness. Diabetologia 2005;48:2684-6. http://dx.doi.org/10.1007/s00125-005-0015-4
13. Curhan GC, Willett WC, Rimm EB, et al. Body size and risk of kidney stones. J Am Soc Nephrol 1998;9:1645-52.

14. Semins $M$, Shore $A$, Makary $M$, et al. The association of increasing body mass index and kidney stone disease. J Urol 2010;183:571-5. http://dx.doi.org/10.1016/i.juro.2009.09.085

15. Onat A, Avci GS, Barlan MM, et al. Measures of abdominal obesity assessed for visceral adiposity and relation to coronary risk. Int J Obes 2004;28:1018-25. http://dx.doi.org/10.1038/si.jio.0802695

16. Allard A, Shuster A, Pinthus JH, et al. Obesometric factors associated with increased skin-to-stone distances in renal stone patients. Can J Urol 2012;19:6554-9.

17. Chatteriee S, Kleinman N, Kapoor A, et al. Computerized tomography measurement of visceral adiposity predicts plasma adiponectin levels and metastatic disease in patients with clear-cell renal cell carcinoma. Current Urol 2008;2:188-93. http://dx.doi.org/10.1159/000209831

18. Pareek G, Hedican SP, Lee FT Jr, et al. Shockwave lithotripsy success determined by skin-to-stone distance on computed tomography. Urology 2005;66:941-4. http://dx.doi.org/10.1016/i.urology.2005.05.011

19. BMI Classification. Global database on body mass index. World Health Organization. 2006. hittp://apps. who.int/bmi/index.jsp?introPage=intro.html. Accessed June 21, 2016.

20. Curhan $\mathrm{GC}$, Willett WC, Rimm EB, et al. A prospective study of dietary calcium and other nutrients and the risk of symptomatic kidney stones. N Engl J Med 1993;328:833-8. http://dx.doi.org/10.1056/ NEJM199303253281203

21. Stamatelou KK, Francis ME, Jones $C A$ et al. Time trends in reported prevalence of kidney stones in the United States: 1976-1994. Kidney Int 2003;63:1817-23. http://dx.doi.org/10.1046/i.15231755.2003.00917.x

22. Siener $R$, Glatz $S$, Nicolay $C$, et al. The role of overweight and obesity in calcium oxalate stone formation. Obes Res 2004;12:106-13. http://dx.doi.org/10.1038/oby.2004.14

23. Rumenapf G, Schmidtler J, Schwille PO. Intestinal calcium absorption during hyperinsulinemic euglycemic glucose clamp in healthy humans. Calcif Tissue Int 1990;46:73-9. http://dx.doi.org/10.1007/ BF02556090

24. Lemann J Jr, Lennon EJ, Piering WR, et al. Evidence that glucose ingestion inhibits net renal tubular reabsorption of calcium and magnesium in man. J Lab Clin Med 1970;75:578-85.

25. Whitehead JP, Richards AA, Hickman IJ et al. Adiponectinda key adipokine in the metabolic syndrome. Diabetes Obes Metab 2006:8:264-80. http://dx.doi.org/10.1111/j.1463-1326.2005.00510.x

26. Trinchieri A. Epidemiology of urolithiasis: An update. Clin Cases Miner Bone Metab 2008;5:101-6.

27. Daudon $M$, Doré $J-C$, Jungers $P$, et al. Changes in stone composition according to age and gender of patients: A multivariable epidemiological approach. Urol Res 2004;32:241-7. http://dx.doi. org/10.1007/s00240-004-0421-y

28. Cho ST, Jung $S \|$, Myung $S C$, et al. Correlation of metabolic syndrome with urinary stone composition. Int J Urol 2013;20:208-13. http://dx.doi.org/10.1111/j.1442-2042.2012.03131.xJames PT, Leach $R$, Kalamara E, et al. The worldwide obesity epidemic. Obesity Res 2001;9:228s-33. http://dx.doi. org/10.1038/oby.2001.123

29. James PT, Leach R, Kalamara E, et al. The worldwide obesity epidemic. Obesity Res 2001;9:228s-33. http://dx.doi.org/10.1038/oby.2001.123

Correspondence: Dr. Derek Bos, McMaster University, Hamilton, ON, Canada; derek.bos@medportal.ca 